\title{
P02.170. Mindfulness-based stress reduction (MBSR) for breast cancer: a systematic review of randomized-controlled trials
}

\author{
H Cramer*, R Lauche, A Paul, G Dobos \\ From International Research Congress on Integrative Medicine and Health 2012 \\ Portland, Oregon, USA. 15-18 May 2012
}

\section{Purpose}

To assess the effectiveness of mindfulness-based stress reduction (MBSR) in patients with breast cancer.

\section{Methods}

MEDLINE, PsychInfo, EMBASE, CAMBASE, and the Cochrane Library were screened through October 2011. Randomized controlled trials (RCTs) comparing MBSR to controls were analyzed. Risk of bias was assessed using the Cochrane risk of bias tool. For each outcome, standardized mean differences (SMD) and 95\% confidence intervals (CI) were calculated, if at least 2 studies assessing this outcome were available. As a measure of heterogeneity, $\mathrm{I}^{2}$ was calculated.

\section{Results}

Three RCTs with a total of 319 subjects were included. One RCT compared MBSR to usual care; one RCT compared MBSR to free choice stress management; and one three-arm RCT compared MBSR to usual care and nutrition education. MBSR was superior to usual care in decreasing depression (SMD $=-0.37$ [95\% CI -0.65 to -0.08 ], $\left.\mathrm{p}=0.01, \mathrm{I}^{2}=0 \%\right)$ and anxiety (SMD $=-0.51[95 \% \mathrm{CI}-0.80$ to -0.21 ], $\mathrm{p}=0.0009, \mathrm{I}^{2}=0 \%$ ) but not in increasing spirituality ( $\mathrm{SMD}=0.27$ [95\% CI -0.37 to 0.91$], \mathrm{p}=0.41, \mathrm{I}^{2} \geq 79 \%$ ).

\section{Conclusion}

There is some evidence of effectiveness of MBSR in improving psychological health in breast cancer patients. However more RCTs are needed to underpin these results.

University of Duisburg, Complementary and Integrative Medicine, Essen, Germany

C Biomed Central
Published: 12 June 2012

doi:10.1186/1472-6882-12-S1-P226

Cite this article as: Cramer et al:: P02.170. Mindfulness-based stress reduction (MBSR) for breast cancer: a systematic review of randomizedcontrolled trials. BMC Complementary and Alternative Medicine 201212 (Suppl 1):P226.
Submit your next manuscript to BioMed Central and take full advantage of:

- Convenient online submission

- Thorough peer review

- No space constraints or color figure charges

- Immediate publication on acceptance

- Inclusion in PubMed, CAS, Scopus and Google Scholar

- Research which is freely available for redistribution
() Biomed Central 